\title{
Carbon stable isotope composition of charophyte organic matter in a small and shallow Spanish water body as a baseline for future trophic studies
}

\author{
María A. RODRIGO ${ }^{*}$, Adriana GARCÍA, ${ }^{2}$ Allan R. CHIVAS $^{2}$ \\ ${ }^{1}$ Integrative Ecology Group, Cavanilles Institute of Biodiversity and Evolutionary Biology, University of Valencia, Catedràtic José \\ Beltran 2, E-46980 Paterna, Spain; ${ }^{2}$ School of Earth and Environmental Sciences, GeoQuEST Research Centre, University of Wollongong, \\ NSW 2522, Australia \\ *Corresponding author: maria.a.rodrigo@uv.es
}

\begin{abstract}
Quantitative descriptions of foodweb structure based on isotope niche space require knowledge of producers' isotopic signatures. In freshwater ecosystems charophytes are one of the main components of submerged vegetation and the feeding base for many herbivorous consumers, but knowledge about their organic carbon isotopic signatures is sparse. In this study, the $\delta^{13} \mathrm{C}$ organic values (and organic $\%$ C and $\% N$ ) of the four species of submerged macrophytes (three charophytes - Chara hispida, Nitella hyalina and Tolypella glomerata - and one angiosperm, Myriophyllum spicatum) growing in a newly created shallow pond were measured monthly over a period of one year, to discern if i) all charophyte species susceptible to being food for consumers and growing in the same waterbody have the same $C$ isotopic composition; ii) the $\delta^{13} C$ values of a charophyte species change on a seasonal and spatial scale; iii) the different parts (apical nodes, internodes, rhizoids, reproductive organs, oospores) of a charophyte species have the same isotopic composition. The $\delta^{13} \mathrm{C}, \% \mathrm{C}$ and $\% \mathrm{~N}$ values of organic matter in the sediments where the plants were rooted were also measured as well as several limnological variables. The $\delta^{13} \mathrm{C}$ values for the angiosperm $\left(-13.7 \pm 0.7 \%\right.$ ) indicated ${ }^{13} \mathrm{C}$-enrichment, whereas the $\mathrm{N}$. hyalina $\delta^{13} \mathrm{C}$ values were the most negative (-22.4 $\pm 0.7 \%$ ). The mean $\delta^{13} \mathrm{C}$ value for C. hispida was $-19.0 \pm 1.0 \%$ and $-20.7 \pm 0.8 \%$ for T. glomerata. C. hispida $\delta^{13} C$ values had a significant seasonal variation with ${ }^{13} C$-poor values in the cold season, and slight spatial differences. Statistically significant differences were found between charophyte rhizoids $\left({ }^{13} \mathrm{C}\right.$-enriched) and the other parts of the thalli. The $\delta^{13} \mathrm{C}$ values in the sediments varied throughout time (-13\%o to -26\%). The C content was lower in the charophytes than in the angiosperm and there were no large differences among the charophytes. Charophyte fructifications were enriched in organic C compared to the thallus parts. The study provides an isotopic baseline for further studies for the elucidation of higher trophic-level relationships which are particularly complex in shallow water bodies where interactions between the pelagic and the benthic zones are intricate.
\end{abstract}

Key words: $\delta^{13} C$ signature; Chara hispida; Nitella hyalina; Tolypella glomerata; Myriophyllum spicatum; Albufera de València Natural Park.

Received: May 2015. Accepted: November 2015.

\section{INTRODUCTION}

Recently developed approaches based on isotope niche space allow quantitative descriptions of food web structure, such as the total extent of trophic diversity and trophic redundancy (Layman et al., 2007; Kovalenko and Dibble, 2011). Stable isotope analysis commonly allows the identification of elemental sources to progressively higher trophic levels (Rossi et al., 2010). However, to do this the knowledge of the isotopic signatures of each producer in the community is required.

Stable isotope ratios have been described as efficient indicators of the abundance of carbon (C) sources for plants (Dawson et al., 2002; Asaeda et al., 2008). The preferential uptake of the lighter isotope by a plant and the availability of sources lead to isotope discrimination (Fry, 1991, 2006). Moreover, C undergoes minimal fractionation caused by consumer activity, in comparison to nitrogen, and can be used to track basal resources (Vander
Zanden and Rasmussen, 2001; Post, 2002). Variation in $\delta^{13} \mathrm{C}$ values in plants may be the result of differences in light intensity and plant productivity and this is linked to several factors, including the nature of the inorganic $\mathrm{C}$ source, the form of $\mathrm{C}$ that is available and that can be assimilated by each species (e.g., $\left.\mathrm{CO}_{2}, \mathrm{HCO}_{3}^{-}\right)$, the photosynthetic pathway used $\left(\mathrm{C}_{3}, \mathrm{C}_{4}, \mathrm{CAM}\right)$, and the limits to diffusion of inorganic $\mathrm{C}$ imposed by plant life-form and habitat (Keeley and Sandquist, 1992; Benson et al., 2008). Three of these sources of variation (all except the photosynthetic pathway) are site-specific, complicating comparisons of species across sites (Keough et al., 1998). A good characterization of several species of plants living in the same aquatic system would help to discern how much of the variation in $\delta^{13} \mathrm{C}$ values is species-specific and how much is environmentally caused.

The trophic relationships are particularly complex in shallow water bodies where the interactions between the pelagic and the benthic zones are intricate (Batt et al., 
2012). In this context, many studies indicate that the consumption of macrophytes is important in aquatic food webs (Lodge, 1991; Newman, 1991; Miller and Provenza, 2007), and charophytes are one of the main components of submerged vegetation in water bodies (Coops, 2002; Kufel and Kufel, 2002).

Charophytes are able to take up nutrients from both above- and belowground organs (Vermeer et al., 2003), therefore all chemical and biological processes occurring in the sediments might also influence the $\delta^{13} \mathrm{C}$ values of the macrophytes. As stated above, beds of macrophytes in general, and of charophytes in particular, provide habitat, shelter and food for many consumers (Coops, 2002). In Spain, in the Albufera de València Natural Park the exotic red swamp crayfish Procambarus clarkii Girard was common in the charophyte beds of a newly created pond. This crayfish species has been found to feed preferentially on charophytes rather than higher plants (Cirujano et al., 2004). Also herbivorous waterfowl (mainly coots) feed directly on the charophyte stands and several species of fish have been detected in the pond (Rodrigo et al., 2015). Benthic invertebrates might feed directly on macrophytes but food could also be indirectly supplied by macrophytes which provide space for attached epiphytes (Jaschinski et al., 2011). However, few studies have reported stable isotope signatures for charophytes so far. The stable isotope composition of charophyte carbonates (from thalli incrustations and oospores) has been measured (Coletta et al., 2001; Andrews et al., 2004; Pentecost et al., 2006; Pełechaty et al., 2010, 2013; Dux et al., 2015). Asaeda and co-authors (2008) determined nutrient sources for the charophytes Chara fibrosa C. Agardh ex Bruzelius and Nitella hyalina (De Candolle) C. Agardh in an Australian lake based on determination of $\delta^{15} \mathrm{~N}$ and $\delta^{13} \mathrm{C}$ signatures. More recently, $\delta^{13} \mathrm{C}$ signatures for Chara zeylanica Willdenow and Nitella furcata (C. Roxburgh ex A. Bruzelius) C. Agardh have been reported in a study from South American lakes (Mendonça et al., 2013).

To apply the isotope-based food web studies it is necessary to know if the primary producers have a static isotope value within the aquatic system and over time or, by contrast, whether a seasonal and spatial variability exists. Furthermore, in the case that consumers only utilize particular portions of the macrophytes, knowledge of the stable isotope values of the different parts of the same macrophyte individual is necessary.

The present study aims to answer questions related to the issues stated above: Do all charophyte species growing in water bodies such as small and shallow ponds have the same isotopic composition $\left(\delta^{13} \mathrm{C}\right)$ ? Does it change on a seasonal scale (annual cycle) or spatially? Does a given charophyte species have the same isotopic composition in different parts (i.e., apical nodes, internodes, rhizoids, reproductive organs, oospores)? The stable isotope compo- sition of several organs of the same plant (roots, leaves, flowers, fruits, etc.) has been studied in several species of terrestrial plants (Muzuka and Shunula, 2006; Cernusak et al., 2009). However, as far as we know no data exist for aquatic plants, nor for charophytes in particular. The present study represents the baseline for future trophic studies based on consumer isotopic values since the $\delta^{13} \mathrm{C}$ values of the macroproducers (all species of submerged macrophytes) which grew in the pond, have been determined.

\section{METHODS}

\section{Study site}

The study site is an artificial shallow pond created within a wetland area under restoration, Tancat de la Pipa, in the Albufera de València Natural Park (Valencia, Spain; Fig. 1a), which at present is a Reserve Area. The Spanish Water Authorities and the Valencian Government transformed 40 ha of former rice fields with the idea of reconstructing environments that could accommodate the past submerged vegetation, which at present has disappeared from the main coastal lagoon (Fig. 1b; Rodrigo et al., 2010; Rodrigo and Alonso-Guillén, 2013; Rodrigo et al., 2013).

One of the constructed systems was a pond to try to mimic the formerly abundant springs in the Natural Park, which nowadays have deteriorated due to desiccation and pollution (Rodrigo et al., 2015). After the construction of the pond basin in 2008, it was fed by groundwater sources via a deep artesian borehole from the end of that year. The pond has a surface area of approximately four ha and mean and maximum depths of $0.9 \mathrm{~m}$ and $2.2 \mathrm{~m}$, respectively. The groundwater inflow is located in the northeast part of the basin, and there is an outlet in the southwest part (Fig. 1c). The area managers planted $M$. spicatum in the pond but this plant did not last longer than June 2009. However, after flooding, the system was immediately covered by charophyte meadows dominated by $C$. hispida, accompanied by $N$. hyalina and T. glomerata. Rodrigo et al. (2015) provide details of the re-vegetation history.

\section{Samples collection and total organic C, total N and isotopic determinations}

Over a one year period (from April 2009 to March 2010) we measured, at monthly intervals, the $\delta^{13} \mathrm{C}$ values of the four species of macrophytes (three charophytes Chara hispida L., Nitella hyalina and Tolypella glomerata (Desvaux) Leonhardi - and one angiosperm, Myriophyllum spicatum $\mathrm{L}$.), as well as the $\mathrm{C}: \mathrm{N}$ ratio (a tracer of source material; Thornton and McManus, 1994) in the organic matter of the macrophytes and the $\delta^{13} \mathrm{C}, \% \mathrm{C}$ and $\% \mathrm{~N}$ values of organic matter in the sediments where the plants were rooted (Supplementary Tab. 1). Charophyte specimens were identified in the field since they are easily 
distinguishable. C. hispida, the dominant species, was collected from four different sites (Fig. 1c; Supplementary Tab. 1). Site 1 was substituted by site 4 in July 2009 because the former was located in a shallow zone, where the charophytes dried when the water level decreased. For $N$. hyalina and T. glomerata the samples were collected from a single site for each species, in the small available patches they formed when they appeared. $N$. hyalina disappeared from the selected site during this study in September 2009, however, in further surveys after the collection of samples for the present study, it was found again in other zones of the pond (Rodrigo et al., 2015). T. glomerata, a vernal species, only appeared in winter time and specimens of this species could be collected from January 2010 to the end of the study. M. spicatum samples were taken only in May and June 2009 because after that the plant completely disappeared from the pond. Macrophyte samples were taken by means of a hook from a boat (in the deeper sites) or manually (in the shallower sites). Six complete specimens of each species were collected each month at each site (to produce three replicates per site, see below). All samples were stored in sealed plastic bags and kept in an insulated cool-box in the field until returned to the laboratory.

Once in the laboratory, the macrophytes were washed thoroughly with dechlorinated tap water to remove attached material (including epiphytes) and gently dried with drying paper. For N. hyalina specimens which develop mucilage, stereomicroscopic examination showed that washing achieved near-complete removal of adhered material. Thus, the biomass of any remaining attached material was unlikely to have significantly influenced the stable isotope values reported here for the studied species. Immediately after the gentle drying, the different parts of the charophytes (i.e., apical nodes, internodal parts and rhizoids) were separated and placed in Eppendorf tubes. For each species, the different parts from two specimens from each site were placed in the same tube to ensure a sufficient amount of sample for the isotope, $\% \mathrm{C}$ and $\% \mathrm{~N}$ determinations. When the charophytes (in the case of C. hispida and Nitella) had developed reproductive organs, more than 100 oogonia and more than 100 antheridia were randomly collected from the six specimens from each site by means of forceps and stored in small tubes to produce a single composite sample from each site and month. The same procedure was followed in the case of oospores. For M. spicatum, the onetwo topmost centimetres of the plant were cut and introduced into the tubes. All macrophyte samples were frozen at $-20^{\circ} \mathrm{C}$ and finally dried using a lyophilizer.

The macrophyte samples were treated twice with $10 \%$ $\mathrm{HCl}$ solution to eliminate the incrustation carbonate and washed with deionised water to remove excess $\mathrm{HCl}$, prior to the determination of isotopic values and total $\mathrm{C}$ and total $\mathrm{N}$ in the organic matter. The remaining material was dried

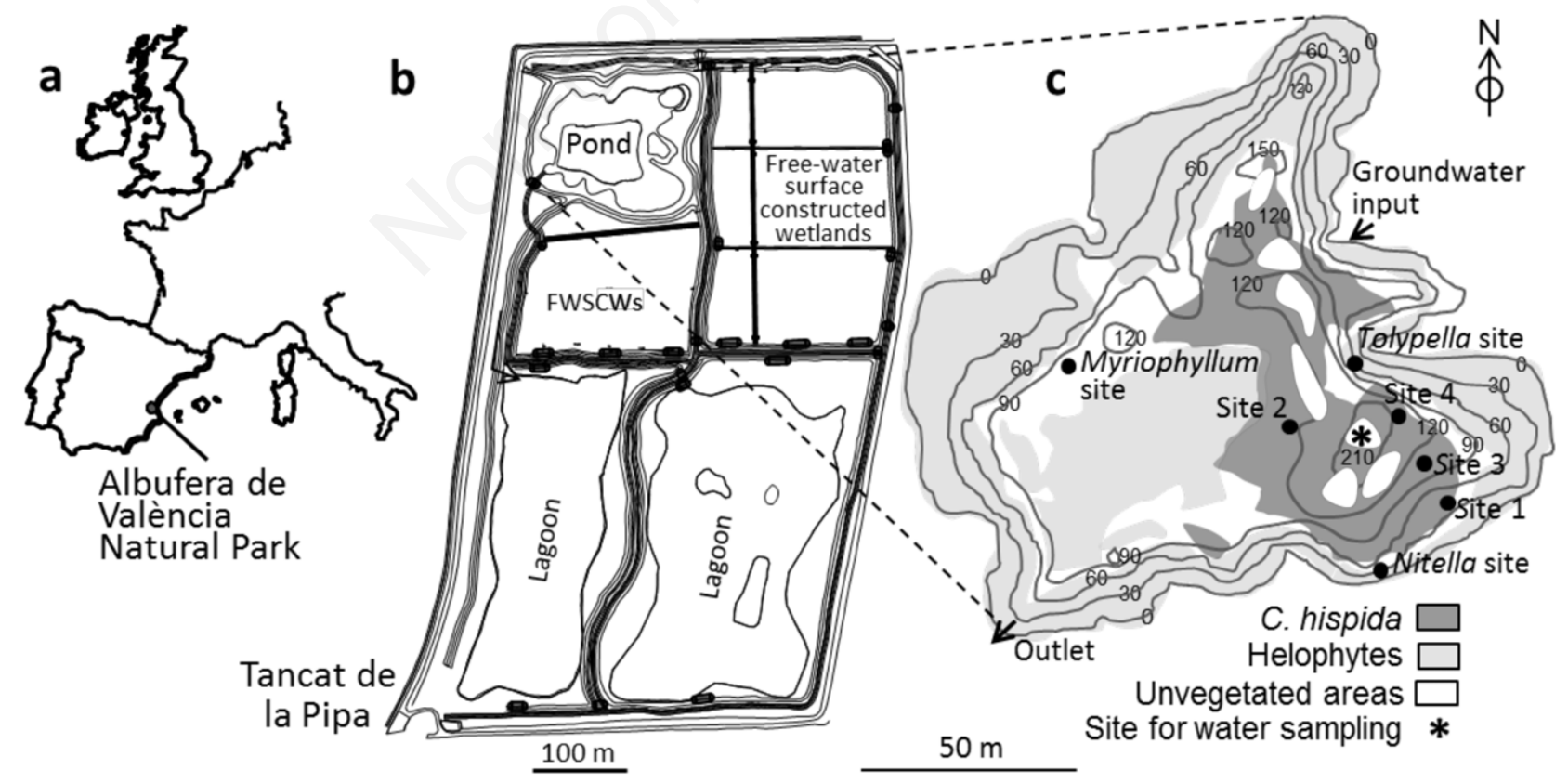

Fig. 1. Location of the study site (a) in the transformed former rice fields (b). c) Sampling sites for macrophytes $(\bullet)$ indicated on the vegetation map from August 2009 and sampling site for water $(*)$ to measure limnological variables (other than $\mathrm{pH}$ and alkalinity). Water depth isobaths are also indicated (in $\mathrm{cm}$ ). FWSCWs: free-water surface constructed wetlands. 
for $48 \mathrm{~h}$ at $60^{\circ} \mathrm{C}$. Later, it was ground and homogenized. $\mathrm{C}$ and $\mathrm{N}$ elemental abundances and $\mathrm{C}$-isotope composition were analyzed on a Carlo Erba NCS1500 elemental analyser coupled to a Micromass Prism III mass spectrometer (University of Wollongong, Australia). One measurement per sample was made, but when there was sufficient material two or three measurements per sample were performed. Approximately, 500 measurements for each variable were made. The processed samples were loaded into $5 \times 9 \mathrm{~mm}$ tin capsules in a 93-well carousel holder. Each analytical run started with eight elemental standards. During the run, two elemental standards were analysed subsequently to every 10 samples. Isotopic results are given using the $\delta$ notation expressed in units of per mil. The overall reproducibility of $\delta^{13} \mathrm{C}$ determinations with this method, including typical sample inhomogeneities and combustion variability is $0.3 \%$. The elemental and isotopic calibration was carried out with ANU (Australian National University) sucrose $\left(42.1 \% \mathrm{C} ;-10.5 \%{ }^{13} \mathrm{C}\right)$, urea $(20.0 \% \mathrm{C} ; 46.9 \% \mathrm{~N}$; $\left.-36.5 \% \delta^{13} \mathrm{C}\right)$, atropine $\left(70.6 \% \mathrm{C} ; 4.8 \% \mathrm{~N} ;-28.5 \%{ }^{13} \mathrm{C}\right)$, benzoic acid $\left(-28.3 \% \delta^{13} \mathrm{C}\right)$, IAEA-C7 Standard Reference Material (SRM) oxalic acid $\left(-14.5 \% \circ \delta^{13} \mathrm{C}\right)$, IAEA-C8 (SRM), oxalic acid $\left(-18.3 \%\right.$ o $\left.\delta^{13} \mathrm{C}\right)$, and NIST (National Institute of Standards and Technology, SRM 1547 peach leaves) $\left(45.3 \% \mathrm{C} ; 2.9 \% \mathrm{~N} ;-25.9 \% \delta^{13} \mathrm{C}\right)$. For more analytical details see Reymond et al. (2013).

Surface (first three $\mathrm{cm}$ ) sediment samples were taken from the four Chara sites and the Nitella site (Supplementary Tab. 1) and introduced into $20-\mathrm{mL}$ plastic tubes. Sediment samples were transported to the laboratory and immediately frozen at $-20^{\circ} \mathrm{C}$ and further lyophilised. Sediment samples were treated twice with $10 \% \mathrm{HCl}$ solution to eliminate carbonate and washed with deionised water to remove excess $\mathrm{HCl}$, prior to the determination of isotopic values and total organic $\mathrm{C}$ and $\mathrm{N}$. The rest of procedure was the same as for macrophyte samples.

\section{Analyses of other physical, chemical and biological variables}

Temperature, dissolved $\mathrm{O}_{2}$, conductivity, total phosphorus, soluble reactive phosphorus, total nitrogen, chemical oxygen demand and sestonic chlorophyll $a$ were determined in each sampling occasion following standard methods (APHA, 1998; for details see Rodrigo et al., 2015). An integrated water sample was taken from the deepest part of the pond to measure these variables (Fig. 1; Supplementary Tab. 1). Alkalinity and $\mathrm{pH}$ values were measured from water taken at the sites of charophyte collection (Supplementary Tab. 1). Alkalinity was measured by the titration method (APHA, 1998) and expressed as $\mathrm{mg} \mathrm{L}^{-1}$ of bicarbonate. Every two months, at three sampling sites, C. hispida samples of $0.034 \mathrm{~m}^{2}$ were taken (using an $18.5 \times 18.5$ $\mathrm{cm}$ frame) to determine their biomass production per surface unit. The samples were transported to the laboratory, washed in water to eliminate residues of sediment and epiphytic algae, dried at $70^{\circ} \mathrm{C}$ and weighed (Rodrigo et al., 2015).

\section{Statistical analyses}

The Levene test was applied to examine the data for homogeneity of variances (homoscedasticity). When this was achieved, one-way or two-way ANOVA tests, depending on the data series, were performed. Bonferroni tests were used as post hoc analyses. When there was lack of homoscedasticity, non-parametric tests or robust ANOVA (Wang et al., 2010) were applied. Inter-species comparisons of $\delta^{13} \mathrm{C}, \% \mathrm{C}$ and $\% \mathrm{~N}$ were performed including only the months when all the species to be compared were present in the pond (Chara/Nitella/Myriophyllum: May-June; Chara/Nitella: May-July; Chara/Tolypella: January-March). Apical $\delta^{13} \mathrm{C}$, $\% \mathrm{C}$ and $\% \mathrm{~N}$ values for $C$. hispida were split into springsummer (April-August) and autumn-winter (SeptemberFebruary) groups and the seasonal means compared by one-way ANOVA tests. Regression analyses were applied to search for any relationships in $\delta^{13} \mathrm{C}, \% \mathrm{C}$ and $\% \mathrm{~N}$ between C. hispida and sediments. Pearson correlation analyses were performed among the mean values of $\delta^{13} \mathrm{C}, \% \mathrm{C}$ and $\% \mathrm{~N}$ for each particular month for $C$. hispida and all the physical, chemical and biological monitored variables. Analyses were carried out with statistical SPSS ${ }^{\circledR}$ (v. 19.0) and R software (v. 3.1.1, Wang et al., 2010).

\section{RESULTS}

\section{Limnological variables}

Water $\mathrm{pH}$ was slightly alkaline throughout the study period. Water alkalinity was approximately $160 \mathrm{mg}$ $\mathrm{HCO}_{3}^{-} \cdot \mathrm{L}^{-1}$ (Tab. 1). No significant differences were found for means in alkalinity (one-way ANOVA, $\mathrm{F}=1.1$, $\mathrm{P}=0.360$ ) and $\mathrm{pH}$ among sites (Kruskal-Wallis test, $\mathrm{P}=0.977$ ) (Supplementary Tab. 2). The mean annual water salinity was $1.9 \pm 0.3 \mathrm{~g} \cdot \mathrm{L}^{-1}$. Nutrient concentrations fluctuated from values typical of oligotrophic to meso-eutrophic waterbodies (Tab. 1), the latter coinciding with the end of the summer when the highest phytoplankton development (chlorophyll $a$ concentrations $>30 \mu \mathrm{g} \cdot \mathrm{L}^{-1}$ ) took place. The biomass of the dominant charophyte species, C. hispida, described an annual pattern, with the growth period beginning in early spring (when temperatures were still low, $12-16^{\circ} \mathrm{C}$ ) and senescence at the end of summer (when the temperatures became high, approximately $30^{\circ} \mathrm{C}$ ), although the meadows overwintered.

\section{Macrophyte isotopic values and relationships with limnological variables}

The $\delta^{13} \mathrm{C}$ mean value for the angiosperm M. spicatum was significantly less negative than those for the charo- 
phytes C. hispida and N. hyalina (one-way ANOVA, $\mathrm{F}=36.7, \mathrm{P}<0.001$; Fig. 2, Tab. 2, Supplementary Tab. 2). Among the charophyte species, $N$. hyalina showed the most negative value. The T. glomerata $\delta^{13} \mathrm{C}$ values were similar to those of $C$. hispida, but differ significantly (two-way ANOVA, F=10.9, $\mathrm{P}=0.003$; Fig. 2, Tab. 2, Supplementary Tab. 2). The Time factor and the interaction Species $x$ Time were also significant (two-way ANOVA, $\mathrm{F}=4.3, \mathrm{P}=0.024$; Supplementary Tab. 2). There were significant differences in $\delta^{13} \mathrm{C}$ values between $C$. hispida individuals collected from different sites (Tab. 2; Supplementary Tab. 2), with site 4 as the most negative. Throughout the annual cycle, the C. hispida $\delta^{13} \mathrm{C}$ value (Fig. 2) was less negative in warmer than in colder months. The mean $\pm \mathrm{SD} \delta^{13} \mathrm{C}$ values for spring-summer and autumn-winter were $-18.2 \% \pm \pm 1.4 \%$ and $-21.0 \% \pm 1.3 \%$, respectively, and the means were statistically different (one-way ANOVA, $\mathrm{F}=116.6, \mathrm{P}<0.001$; Supplementary Tab. 2). There was also a significant correlation between $C$. hispida $\delta^{13} \mathrm{C}$ and $\mathrm{pH}$ values $(\mathrm{r}=-0.78$, $\mathrm{P}=0.002$; Supplementary Tab. 3 ), the less negative $\delta^{13} \mathrm{C}$ values coincided with the lower $\mathrm{pH}$ values. From the rest of the physical, chemical and biological variables, only sestonic chlorophyll $a$ and the chemical oxygen demand were significantly correlated to $C$. hispida $\delta^{13} \mathrm{C}$ values $(\mathrm{r}=-0.69$, $\mathrm{P}=0.010$, and $\mathrm{r}=-0.63, \mathrm{P}=0.022$, respectively; Supplementary Tab. 3).

\section{$\delta^{13} \mathrm{C}$ values in the different parts of the charophytes}

Charophyte rhizoids had a significantly lower negative mean $\delta^{13} \mathrm{C}$ value than the other parts of the macroalgae. In C. hispida, sexual organ and oospore $\delta^{13} \mathrm{C}$ values were not statistically different compared to the rest of the charophytes in the months when the fructifications occurred (one-way ANOVA, F=0.2, P=0.654; Tab. 2, Supplementary Tab. 2).

\section{$\% \mathrm{C}$ and $\% \mathrm{~N}$ content in macrophyte organic matter}

The organic $\mathrm{C}$ content was statistically lower in the charophytes than in the angiosperm (Bonferroni post hoc, $\mathrm{P}<0.001$; Tab. 2, Supplementary Tab. 2). There were no large differences among the charophyte species. There were no significant differences in the $\mathrm{N}$ content among the macrophyte species (one-way ANOVA, $\mathrm{F}=2.6$, $\mathrm{P}=0.100$; Tab. 2, Supplementary Tab. 2). The C content between $C$. hispida individuals collected from different sites was not statistically different (Tab. 2, Supplementary Tab. 2). Oogonia plus antheridia and oospores in $C$. hispida had higher $\mathrm{C}$ (one-way ANOVA, $\mathrm{F}=44.3$, $\mathrm{P}<0.001$ ), and $\mathrm{N}$ (one-way ANOVA, $\mathrm{F}=8.2, \mathrm{P}=0.005$ ) contents than the rest of the charophyte (thalli) during the months when these structures were developed $(43 \%$ vs

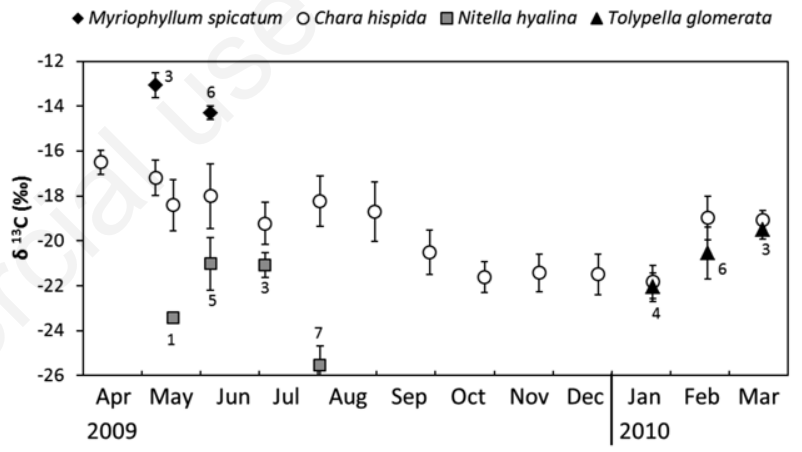

Fig. 2. Time series of $\delta^{13} \mathrm{C}$ values in the apical parts of the three charophyte species and in Myriophyllum spicatum. The vertical bars indicate standard deviations. The numbers indicate the averaged data (n) for Nitella hyalina, Tolypella glomerata and $M$. spicatum. For Chara hispida $\mathrm{n}=6-18$.

Tab. 1. Mean annual values (with standard deviation, $\mathrm{SD} ; \mathrm{n}=13, n_{C \text {. hispida biomass }}=6$ ) and ranges of the main limnological variables in the pond from April 2009 to March 2010 including the biomass per unit surface area of the dominant charophyte species.

\begin{tabular}{|c|c|c|c|}
\hline Variable & & Mean \pm SD & Min-Max \\
\hline Temperature & ${ }^{\circ} \mathrm{C}$ & $20.2 \pm 8.5$ & $6.9-30.3$ \\
\hline Dissolved $\mathrm{O}_{2}$ & $\mathrm{mgO}_{2} \mathrm{~L}^{-1}$ & $8.3 \pm 2.7$ & $5.0-12.6$ \\
\hline Conductivity & $\mu \mathrm{S} \mathrm{cm}{ }^{-1}$ & $3824 \pm 539$ & $2780-4490$ \\
\hline $\mathrm{pH}$ & & $7.7 \pm 0.4$ & $7.0-8.2$ \\
\hline Alkalinity & 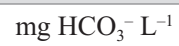 & $159 \pm 4$ & $150-164$ \\
\hline $\mathrm{TP}$ & $\mathrm{mgP} \mathrm{L}^{-1}$ & $0.04 \pm 0.01$ & $0.01-0.05$ \\
\hline $\mathrm{PO}_{4}-\mathrm{P}$ & $\mathrm{mgP} \mathrm{L}^{-1}$ & $<0.005$ & $*$ \\
\hline TN & $\mathrm{mgN} \mathrm{L}^{-1}$ & $0.7 \pm 0.4$ & $0.2-1.3$ \\
\hline Chem. $\mathrm{O}_{2}$ demand ${ }_{\text {tot }}$ & $\mathrm{mgO}_{2} \mathrm{~L}^{-1}$ & $23 \pm 10$ & $6-36$ \\
\hline Chl $a$ & $\mu \mathrm{g} \mathrm{L}^{-1}$ & $17 \pm 8$ & $2-33$ \\
\hline C. hispida biomass & $\mathrm{kgDW} \mathrm{m}^{-2}$ & $0.94 \pm 0.35$ & $0.53-1.32$ \\
\hline
\end{tabular}

$T P$, total phosphorus; TN, total nitrogen; SRP, soluble reactive phosphorus; Chem. $\mathrm{O}_{2}$ demand ${ }_{\text {tor }}$ total chemical oxygen demand; Chl a, sestonic chlorophyll a; DW, dry weight; *0.005 $\mathrm{mg} \mathrm{L}^{-1}$ of $\mathrm{PO}_{4}-\mathrm{P}$ was the detection limit of the method used, and all values were below this level. 
$39 \%, 1.2 \%$ vs $2.1 \%$, C and N, respectively) (Tab. 2, Supplementary Tab. 2). Overall, the above-ground parts of $C$. hispida and $N$. hyalina had a significantly higher $\mathrm{C}$ content than the rhizoids. The $\mathrm{N}$ content was also statistically higher in the upper parts than in the lower parts. For $T$. glomerata, only the $\mathrm{C}$ content was significantly higher in the apical parts than in the rhizoids (Bonferroni post-hoc, $\mathrm{P}=0.042$; Tab. 2, Supplementary Tab. 2).

\section{$\delta^{13} \mathrm{C}, \% \mathrm{C}$ and $\% \mathrm{~N}$ values in the sediment}

The $\delta^{13} \mathrm{C}$ organic values in the sediments where the plants were growing varied throughout time from $-13 \%$ to $-26 \%$ (Fig. 3). On most occasions, site 2 for $C$. hispida presented more negative $\delta^{13} \mathrm{C}$ values (-22\%0), particularly from September 2009 onwards, site 4 had more positive $\delta^{13} \mathrm{C}$ values $(-17 \%)$ and these differences were significant (one-way ANOVA, F=4.9, $\mathrm{P}=0.014$; Supplementary Tab. 2). There was no significant relationship between $\delta^{13} C$ values in the organic matter of the sediment and the charophytes when the overall dataset was considered $(\mathrm{r}=-0.15, \mathrm{P}=0.405$; Supplementary Tab. 3). However, for site $2, \delta^{13} \mathrm{C}$ values for sediment and $C$. hispida rhizoids were significantly correlated $(\mathrm{r}=0.62, \mathrm{P}=0.031$; Supplementary Tab. 3$)$. The $\% \mathrm{C}$ and $\% \mathrm{~N}$ annual means (clustering sites) in sediments were $5.3 \pm 1.6$ $\%$ and $0.4 \pm 0.2 \%$, respectively, and there were no statistical differences among sites.

\section{DISCUSSION}

Do all macrophyte species growing in the same water body have the same $\mathrm{C}$ isotopic composition?

The answer to this question is clearly a negative one. The angiosperm M. spicatum was more ${ }^{13} \mathrm{C}$-enriched than the charophytes. There were also differences among the charophyte species. The reasons for these differences can be varied: i) although submerged macrophytes are prima-

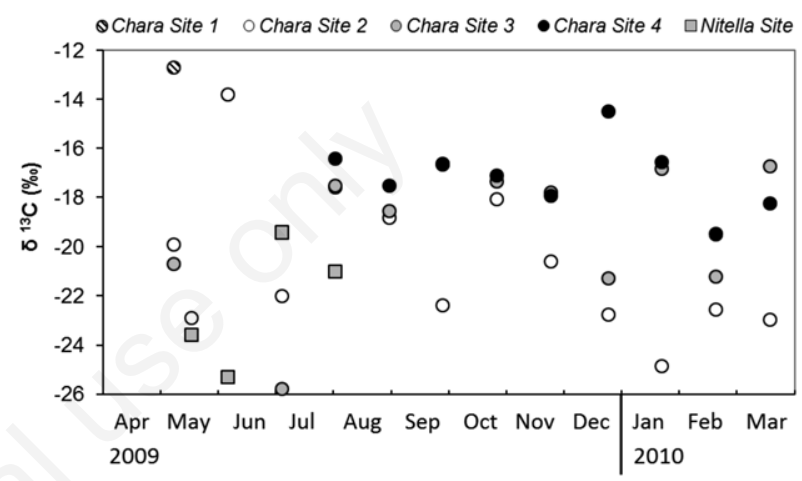

Fig. 3. Time series of $\delta^{13} \mathrm{C}_{\text {organic }}$ values in the sediments where the plants were growing.

Tab. 2. Mean annual values (S.D.: standard deviation, $\mathrm{n}$ : number of averaged values) of $\delta^{13} \mathrm{C}$ and $\mathrm{C}$ and $\mathrm{N}$ contents (in \%) in the vegetative parts of the charophyte species and $M$. spicatum. The same data are presented for the different organs of the charophytes, and for the apical parts of $C$. hispida specimens collected from different sites. The $\mathrm{C} / \mathrm{N}$ molar ratio is also indicated.

\begin{tabular}{|c|c|c|c|c|c|c|c|c|}
\hline & \multirow[t]{2}{*}{ n } & \multicolumn{2}{|l|}{$\delta^{13} \mathrm{C}$} & \multicolumn{2}{|l|}{$\% \mathrm{C}$} & \multicolumn{2}{|l|}{$\% \mathrm{~N}$} & \multirow[t]{2}{*}{$\mathrm{C} / \mathrm{N}$} \\
\hline & & Mean & SD & Mean & SD & Mean & SD & \\
\hline Chara hispida & 403 & -19.0 & 1.0 & 39 & 2 & 2.0 & 0.6 & 23 \\
\hline Nitella hyalina & 33 & -22.4 & 0.7 & 37 & 2 & 2.1 & 0.9 & 21 \\
\hline Tolypella glomerata & 28 & -20.7 & 0.8 & 36 & 3 & 2.9 & 0.8 & 14 \\
\hline Myriophyllum spicatum & 13 & -13.7 & 0.7 & 47 & 2 & 2.6 & 1.2 & 21 \\
\hline \multicolumn{9}{|l|}{ Chara hispida } \\
\hline Apical node & 147 & -19.4 & 0.9 & 39 & 2 & 1.9 & 0.5 & 24 \\
\hline Internodal part & 133 & -19.3 & 1.2 & 39 & 2 & 1.9 & 0.5 & 23 \\
\hline Rhizoids & 123 & -18.4 & 1.0 & 38 & 2 & 2.2 & 0.6 & 20 \\
\hline Oogonia+antheridia & 10 & -17.8 & 0.3 & 42 & 3 & 1.2 & 0.3 & 42 \\
\hline Oospores & 15 & -19.5 & 0.7 & 44 & 2 & 1.2 & 0.1 & 42 \\
\hline \multicolumn{9}{|l|}{ Nitella hyalina } \\
\hline Apical node & 16 & -22.8 & 0.9 & 38 & 3 & 2.6 & 1.2 & 17 \\
\hline Internodal part & 10 & -24.9 & 0.6 & 38 & 1 & 1.4 & 0.3 & 32 \\
\hline Rhizoids & 7 & -21.0 & 0.4 & 36 & 1 & 1.5 & 0.4 & 28 \\
\hline Oospores & 3 & -24.7 & - & 45 & - & 1.4 & - & 39 \\
\hline \multicolumn{9}{|l|}{ Tolypella glomerata } \\
\hline Apical node & 13 & -20.7 & 1.3 & 38 & 2 & 3.5 & 1.4 & 13 \\
\hline Internodal part & 9 & -21.7 & 2.0 & 38 & 2 & 3.1 & 1.0 & 14 \\
\hline Rhizoids & 6 & -19.7 & 0.7 & 34 & 5 & 2.4 & 0.6 & 16 \\
\hline C. hispida Site 1 & 8 & -18.7 & 1.5 & 41 & 1 & 1.0 & 0.3 & 47 \\
\hline C. hispida Site 2 & 59 & -18.8 & 0.7 & 40 & 2 & 2.1 & 0.5 & 22 \\
\hline C. hispida Site 3 & 46 & -19.5 & 0.6 & 39 & 2 & 2.1 & 0.6 & 22 \\
\hline C. hispida Site 4 & 34 & -20.6 & 0.7 & 39 & 2 & 2.3 & 0.5 & 20 \\
\hline
\end{tabular}


rily $\mathrm{C}_{3}$ plants they can exhibit a continuum of photorespiratory states that can produce variations in $\mathrm{C}$ fractionation (Keeley and Sandquist, 1992); ii) higher use of $\mathrm{HCO}_{3}^{-}$by the angiosperm $\left(\mathrm{HCO}_{3}{ }^{-}\right.$has more enriched ${ }^{13} \mathrm{C}$ values than $\mathrm{CO}_{2}$ : $-2 \%$ and $-11 \%$, respectively, Deuser and Degens, 1967; Mook et al., 1974); iii) slight differences in plant architecture among species that might cause differential C limitation (Keough et al., 1998).

At the range of $\mathrm{pH}$ found in the studied pond, most dissolved inorganic $\mathrm{C}$ occurs in the form of $\mathrm{HCO}_{3}^{-}$; however, lower $\mathrm{pH}$ values (close to 7) were registered during the months when $M$. spicatum lived in the pond, and, thus, both forms of dissolved inorganic $\mathrm{C}$ were available in different relative concentrations compared to the periods of higher $\mathrm{pH}$. C. hispida and N. hyalina were also present during the months of lower $\mathrm{pH}$ and their $\delta^{13} \mathrm{C}$ values were different to those of $M$. spicatum. Thus, the other reasons might have also been influencing the ${ }^{13} \mathrm{C}$ content in the macrophytes in the pond. The phylogenetic differences in the macrophytes that inhabit the pond are evident (plants versus macroalgae, different genera of charophytes). Others authors also found more ${ }^{13} \mathrm{C}$-enriched values in angiosperms than in charophytes. $N$. hyalina values from the studied pond correspond more with a ${ }^{13} \mathrm{C}$-depleted macrophyte group from 19 South American lakes (group average of -27.2\%o, Mendonça et al., 2013) and M. spicatum approaches the ${ }^{13} \mathrm{C}$-enriched group (group average of 13.5\%o), with C. hispida and T. glomerata between. Particularly, M. spicatum $\delta^{13} \mathrm{C}$ values were close to the average $\delta^{13} \mathrm{C}$ values of Myriophyllum quitense Kunth (-15\%o) in the study of Mendonça et al. (2013), less negative than those for Chara spp. (-23\%o).

Asaeda et al. (2008) also found a higher ${ }^{13} \mathrm{C}$ content in the aquatic plant Najas marina $(-7 \%$ ) in comparison to charophytes $(-10 \%$ o to $-14 \%$ ) from the same waterbody. It is remarkable that Nitella and Tolypella section Tolypella are phylogenetically closer, yet our results indicate that the Chara and Tolypella $\delta^{13} \mathrm{C}$ values are more similar. Submersed plants have to contend with aqueous resistance to diffusion of DIC (Keeley and Sandquist, 1992). C limitation might be produced from boundarylayer diffusion resistance around leaves (or other plant surfaces, including epiphytes), and it might force the macrophyte to maximize the use of internal inorganic $\mathrm{C}$ and to recycle $\mathrm{C}$ (Wetzel et al., 1985). As a result of it reduced photosynthetic plant discrimination against the heavier isotope occurs and plant tissues have more depleted $\delta^{13} \mathrm{C}$ values. Plant architecture is clearly different between the studied macrophytes: the angiosperm has finely dissected leaves, but Nitella hyalina also has divided branchlets and it is in the other extreme of $\delta^{13} \mathrm{C}$ values; Chara and Tolypella show undivided branchlets and have intermediate $\delta^{13} \mathrm{C}$ values. Phylogenetic affiliation, differential use of $\mathrm{HCO}_{3}{ }^{-}$, different $\mathrm{C}$ limitation, different efficiency in $\mathrm{C}$ assimilation and/or morphological differences in plant architecture have resulted in the range of $\delta^{13} \mathrm{C}$ values in the macro primary producers found in the studied pond. However, with our data, we are not able to conclude which ones of the above mentioned reasons are the most important to cause the different $\delta^{13} \mathrm{C}$ values in the macrophyte species. A longer comparable data series would also be desirable to precisely discern the semblances or differences in Chara and Tolypella $\mathrm{C}$ stable isotopic composition.

\section{Do the $\delta^{13} \mathrm{C}$ values change on a seasonal scale (annual cycle) and/or spatially for the same species?}

Our data indicate that the answer is yes; in the case of the apical parts of $C$. hispida the difference in $\delta^{13} \mathrm{C}$ mean values throughout the annual cycle can be as high as $5.3 \%$. Variability in $\delta^{13} \mathrm{C}$ values of primary producers in freshwater ecosystems may be related to the plant's development status, as well as the nutrient contents in tissues, which vary according to the growth phase of plants (Fernández-Aláez and Fernández-Aláez, 2011). But the $\delta^{13} \mathrm{C}$ values also can vary depending on the baseline hydrological characteristics or nutrient enrichment in the waterbody (Sierzen et al., 2006). Sebastián-González et al. (2012) found differences in $\delta^{13} \mathrm{C}$ values for Potamogeton $\mathrm{sp}$. by comparing the submerged life status to the more developed status with floating leaves, changing to more depleted ${ }^{13} \mathrm{C}$ content.

In the studied pond, during autumn-winter time, $C$. hispida thalli were more ${ }^{13} \mathrm{C}$-depleted. Although the species overwinters in the pond, it exhibits a clear annual cycle in growth (Rodrigo et al., 2015) mainly affecting the total length of the charophytes: during the warm season the apical parts of the specimens reach the water surface and during the cold season these are located deeper. Accordingly, it could be expected that the taller plants could have been using more atmospheric $\mathrm{CO}_{2}$ which could have been found in higher concentration in the surface water layers while the apical parts of the charophyte located deeper during the cool months would have been using $\mathrm{HCO}_{3}{ }^{-}$instead, generating a more enriched ${ }^{13} \mathrm{C}$ signal. However, the observed pattern is just the opposite.

Light regime differences caused markedly different $\delta^{13} \mathrm{C}$ values (from $-17.6 \%$ o to $-5.5 \%$ ) during an experiment with seagrass species (Grice et al., 1996). In the studied pond, C. hispida was also subjected to different underwater light climate depending mainly on the season and on the microalgal development (Rodrigo et al., 2015). Water $\mathrm{pH}$ is the chemical variable most related to the annual variation of $\delta^{13} \mathrm{C}$ in the apical parts of $C$. hispida, although the covariation is the opposite to the expected trend based on the difference in the relative concentrations of $\mathrm{HCO}_{3}$ and $\mathrm{CO}_{2}$ at different $\mathrm{pH}$ values. However, the more negative $\delta^{13} \mathrm{C}$ values of $C$. hispida during winter might be ex- 
plained by less $\mathrm{C}$ limitation due to lower growth or production rates during the unfavourable season.

Although several studies have reported major differences in the isotopic values of the same species among different water bodies (see Sebastián-González et al., 2012 and references therein) there is little information about isotope variability within the same ecosystem for a particular species (Syväranta et al., 2006). Our results show that there were differences between the $\delta^{13} \mathrm{C}$ values of $C$. hispida specimens taken from different sites, but these differences were small (2\%) and mainly originated from the values obtained in the deepest site. Charophytes are able to take up nutrients from both above- and belowground organs (Vermeer et al., 2003) and the sedimentary environment was not identical, as indicated by the $\delta^{13} \mathrm{C}$ values of the organic matter in the sediments, which was variable most of the time among sites. One of the reasons for these differences lies in the procedures used in the construction of the pond basin by means of machinery, to transform the former rice fields into the current Reserve Area. The sediments were disturbed and unevenly spatially distributed, since layers from different ages were brought to the surface (Rodrigo et al., 2015). Moreover, it has been proposed that charophytes in soft-sediment lakes obtain a part of their inorganic $\mathrm{C}$ via sediment respiration, which produces diffusion of $\mathrm{CO}_{2}$ from sediments to lake water in Chara-dominated lakes (Christensen et al., 2013) and some of this $\mathrm{CO}_{2}$ must end up in the plants. Thus, the organic $\mathrm{C}$ in sediments needs to be considered as a potentially important source, after transformation, of inorganic $\mathrm{C}$ for charophytes.

\section{Do the different parts of a given charophyte species have the same $\delta^{13} \mathrm{C}$ values (and $\mathrm{C}$ and $\mathrm{N}$ content)?}

Non-photosynthetic, or heterotrophic, tissues (woody stems and roots) in terrestrial $\mathrm{C}_{3}$ plants have been described to be enriched in ${ }^{13} \mathrm{C}$ compared with the leaves (Cernusak et al., 2009). The enrichment in ${ }^{13} \mathrm{C}$ in the roots averages $1.1 \%$ but the strength of enrichment varies among species (Badeck et al., 2005). In the studied pond, the charophyte rhizoids were enriched by $1.5 \%$ - $2.8 \%$ o compared to the above-sediment parts. Young, emerging leaves of $\mathrm{C}_{3}$ plants, for which growth may be mostly nonphotosynthetic, tend to be ${ }^{13} \mathrm{C}$ enriched compared to fullyexpanded leaves (Holtum and Winter, 2005). The apical parts of the charophytes cannot be seen as analogous to the emerging leaves of trees since, due to the apical growth of charophytes, these parts are the most active photosynthetically. The greater $\mathrm{C}$ and $\mathrm{N}$ content in the apical parts of $N$. hyalina could be explained by the presence of some remaining mucus; mucilage formation is a typical feature of this species. Seeds and fruits have been also described to be ${ }^{13} \mathrm{C}$-enriched compared with leaves in $\mathrm{C}_{3}$ terrestrial plants (Cernusak et al., 2009). The fertilized egg cells in charophytes which produce resistant, thick-walled zygotes rich in starch called oospores, did not show significantly enriched ${ }^{13} \mathrm{C}$ values in comparison to other parts of the charophytes. However, the $\mathrm{C}$ content and the $\mathrm{C} / \mathrm{N}$ ratio were the highest in the oospores, perhaps as their $\mathrm{C}$ rich compounds are stored to be further used during germination (Bonis and Grillas, 2002).

\section{CONCLUSIONS}

From this study, some recommendations can be given for systems similar to this pond.

i) Charophytes do not have static $\delta^{13} \mathrm{C}$ values over time; they exhibit annual variability which might be as high as the difference in the $\delta^{13} \mathrm{C}$ values among different species; therefore, at least seasonal samplings are recommended for the determination of $\delta^{13} \mathrm{C}$ values for trophic studies based on isotopic signatures.

ii) However, since no relevant differences have been found between different parts of the above-sediment parts of the charophytes that might be relevant for the herbivores (e.g., apical vs basal parts), the extra work involved in separating these parts is not recommended.

iii) Macrophytes, in particular charophytes, precipitate calcium carbonate in the form of incrustations on the tissues (Kufel et al., 2013) that in the case of the studied pond can reach, at certain times, a value which is nearly $55 \%$ of the total dry weight of the charophyte biomass (Rodrigo et al., 2015). Herbivores consume the whole plant, they assimilate the organic $\mathrm{C}$ but what happens with the ingested inorganic $\mathrm{C}$ remains unknown. Therefore, trophic studies based on isotopic values have to be made after the incrustations have been carefully removed, otherwise the bulk $\delta^{13} \mathrm{C}$ values may be inappropriate, but also separately evaluating the stable isotope composition of the carbonate incrustations.

The variability in the $\delta^{13} \mathrm{C}$ values for a given charophyte species, but also the lack of large differences among species, indicate the challenge aquatic ecologists face in identifying $\mathrm{C}$ sources for higher trophic levels when environmental conditions vary and similar species are present.

\section{ACKNOWLEDGMENTS}

MAR was the holder of a visiting fellowship (BEST/2009/004, Generalitat Valenciana) to the School of Earth and Environmental Sciences (University of Wollongong) during July-August 2009. The authors thank David Wheeler (University of Wollongong) for his assistance with the isotopic analyses. We thank J.L. AlonsoGuillén, F. Rubio, A. Campos, C. Rojo and E. García (ICBiBE, University of Valencia) for their assistance in field, laboratory and statistical work. We are grateful for 
the collaboration of Dr M. Martín and his team (IIAMA, Polytechnic University of Valencia) who kindly carried out the chemical analyses. We also thank Dr E. Garay (University of Valencia) for allowing us to use the lyophilizer system.

This study was partly funded by project CGL 2009 10292 (Spanish Ministry of Science and Innovation-Economy and Competitiveness). The final version was English edited by Daniel Sheerin (Online English S.C.). We are also grateful to two anonymous reviewers who contributed to improve the manuscript with their suggestions.

\section{REFERENCES}

Andrews JP, Coletta P, Pentecost R, Riding S, Dennis S, Dennis PF, Spiro B, 2004. Equilibrium and disequilibrium stable isotope effects in modern charophyte calcites: implications for palaeoenvironmental studies. Palaeogeogr. Palaeoclimatol. Palaeoecol. 204:101-114.

APHA, 1998. Standard Methods for the Examination of Water and Wastewater, 20th ed. American Public Health Association, Washington, DC, USA.

Asaeda T, Yamamuro M, Siong K, Rajapakse L, Sanderson B, 2008. Nutrient sources for charophytes and Najas marina in Myall Lake, Australia, indicated by carbon and nitrogen stable isotope ratios. Verh. Internat. Verein. Limnol. 30:401-405.

Badeck FW, Tcherkez G, Nogues S, Piel C, Ghashghaie J, 2005. Postphotosynthetic fractionation of stable carbon isotopes between plant organs - a widespread phenomenon. Rapid Commun. Mass Spectrom. 19:1381-1391.

Batt RD, Carpenter SR, Cole JJ, Pace ML, Cline TJ, Johnson RA, Seekell DA, 2012. Resources supporting the food web of a naturally productive lake. Limnol. Oceanogr. 57:1443-1452.

Benson ER, O'Neil JM, Dennison WC, 2008. Using the aquatic macrophyte Vallisneria americana (wild celery) as a nutrient bioindicator. Hydrobiologia 596:187-196.

Bonis A, Grillas P, 2002. Deposition, germination and spatiotemporal patterns of charophyte propagule banks: a review. Aquat. Bot. 72:235-248.

Cernusak LA, Tcherkez G, Keitel C, Cornwell WK, Santiago LS, Knohl A, Barbour MM, Williams DG, Reich PB, Ellsworth DS, Dawson TE, Griffiths HG, Farquhar GD, Wright IJ, 2009. Viewpoint: Why are non-photosynthetic tissues generally $\mathrm{C}-13$ enriched compared with leaves in C-3 plants? Review and synthesis of current hypotheses. Funct. Plant. Biol. 36:199-213.

Christensen JPA, Sand-Jensen K, Staehr PA, 2013. Fluctuating water levels control water chemistry and metabolism of a charophyte-dominated pond. Freshwater Biol. 58:1353-1365.

Cirujano S, Camargo JA, Gómez-Cordovés C, 2004. Feeding preference of the red swamp crayfish Procambarus clarkii (Girard) on living macrophytes in a Spanish wetland. J. Freshw. Ecol. 19:219-226.

Coletta P, Pentecosta A, Spiro B, 2001. Stable isotopes in charophyte incrustations: relationships with climate and water chemistry. Palaeogeogr. Palaeoclimatol. Palaeoecol. 173:9-19.

Coops H, 2002. Ecology of charophytes: an introduction. Aquat. Bot. 72:205-208.

Dawson TE, Mambelli S, Plamboeck AH, Templer PH, Tu KP,
2002. Stable isotopes in plant ecology. Annu. Rev. Ecol. Syst. 33:507-559.

Deuser WG, Degens ET, 1967. Carbon isotope fractionation in the system $\mathrm{CO}_{2}$ (gas)- $\mathrm{C}$ (aqueous)- $\mathrm{HCO}_{3}$ (aqueous). Nature 215:1033-1035.

Dux FW, Chivas AR, García A, 2015. Trace-element and stableisotope chemistry of gyrogonites of the euryhaline charophyte Lamprothamnium. Aquat. Bot. 120:51-59.

Fernández-Aláez C, Fernández-Aláez M, 2011. Seasonal changes in tissue nutrient concentrations of macroalgae and aquatic angiosperms in Mediterranean ponds (North-Western Spain). Fundam. Appl. Limnol. 179:179-192.

Fry B, 1991. Stable isotope diagrams of fresh-water food webs. Ecology 72:2293-2297.

Fry B, 2006. Stable Isotope Ecology. Springer, New York.

Grice AM, Loneragan NR, Dennison WC, 1996. Light intensity and the interactions between physiology, morphology and stable isotope ratios in five species of seagrass. J. Exp. Mar. Biol. Ecol. 195:91-110.

Holtum JAM, Winter K, 2005. Carbon isotope composition of canopy leaves in a tropical forest in Panama throughout a seasonal cycle. Trees-Struct. Funct. 26:545-551.

Jaschinski S, Brepohl DC, Sommer U, 2011. The trophic importance of epiphytic algae in a freshwater macrophyte system (Potamogeton perfoliatus L.): stable isotope and fatty acid analyses. Aquat. Sci. 73:91-101.

Keeley JE, Sandquist DR, 1992. Carbon - Fresh-Water Plants. Plant. Cell. Environ. 15:1021-1035.

Keough JR, Hagley CA, Ruzycki E, Sierszen M, 1998. $\delta^{13} \mathrm{C}$ composition of primary producers and role of detritus in a freshwater coastal ecosystem. Limnol. Oceanogr. 43:734-740.

Kovalenko KE, Dibble ED, 2011. Effects of invasive macrophyte on trophic diversity and position of secondary consumers. Hydrobiologia 663:167-173.

Kufel L, Kufel I, 2002. Chara beds acting as nutrient sinks in shallow lakes - a review. Aquat. Bot. 72:249-260.

Kufel L, Biardzka E, Strzałek M, 2013. Calcium carbonate incrustation and phosphorus fractions in five charophyte species. Aquat. Bot. 109:54-57.

Layman CA, Arrington DA, Montaña CG, Post DM, 2007. Can stable isotope ratios provide for community-wide measures of trophic structure? Ecology 88:42-48.

Lodge DM (1991) Herbivory on fresh-water macrophytes. Aquat. Bot. 41:195-224.

Mendonça R, Kosten S, Lacerot G, Mazzeo N, Roland F, Ometto JP, Alonso Paz E, Petean Bove C, Bueno NC, Gomes JHC, Scheffer M, 2013. Bimodality in stable isotope composition facilitates the tracing of carbon transfer from macrophytes to higher trophic levels. Hydrobiologia 710: 205-218.

Miller SA, Provenza FD, 2007. Mechanisms of resistance of freshwater macrophytes to herbivory by invasive juvenile common carp. Freshwater Biol. 52:39-49.

Mook WG, Bommerso JC, Staverma WH, 1974. Carbon isotope fractionation between dissolved bicarbonate and gaseous carbon-dioxide. Earth Planet Sci. Lett. 22:169-176.

Muzuka ANN, Shunula JP, 2006. Stable isotope compositions of organic carbon and nitrogen of two mangrove stands along the Tanzanian coastal zone. Estuar. Coast Shelf Sci. 66:447-458. 
Newman RM, 1991. Herbivory and detritivory on fresh-water macrophytes by invertebrates: a review. J. N. Am. Benthol. Soc. 10:89-114.

Pełechaty M, Apolinarska K, Pukacz A, Krupska J, Siepak M, Boszke P, Sinkowski M, 2010. Stable isotope composition of Chara rudis incrustation in Lake Jasne, Poland. Hydrobiologia 656:29-42.

Pełechaty M, Pukacz A, Apolinarska K, Pełechata A, Siepak M, 2013. The significance of Chara vegetation in the precipitation of lacustrine calcium carbonate. Sedimentology 60:1017-1035.

Pentecost A, Andrews JE, Dennis PF, Marca-Bell A, Dennis S, 2006. Charophyte growth in small temperate water bodies: Extreme isotopic disequilibrium and implications for the palaeoecology of shallow marl lakes. Palaeogeogr. Palaeoclimatol. Palaeoecol. 240:389-404.

Post DM, 2002. Using stable isotopes to estimate trophic position: models, methods, and assumptions. Ecology 83:703-718.

Reymond CE, Roff G, Chivas AR, Zhao J-X, Pandolfi JM, 2013. Millennium-scale records of benthic foraminiferal communities from the central Great Barrier Reef reveal spatial differences and temporal consistency. Palaeogeogr. Palaeoclimatol. Palaeoecol. 374:52-61.

Rodrigo MA, Alonso-Guillén JL, Soulié-Märsche I, 2010. Reconstruction of the former charophyte community out of the fructifications identified in Albufera de València lagoon sediments. Aquat. Bot. 92:14-22.

Rodrigo MA, Alonso-Guillén JL, 2013. Assessing the potential of Albufera de València Lagoon sediments for the restoration of charophyte meadows. Ecol. Eng. 60:445-452.

Rodrigo MA, Rojo C, Alonso-Guillén JL, Vera P, 2013. Restoration of two small Mediterranean lagoons: the dynamics of submerged macrophytes and factors that affect the success of revegetation. Ecol. Eng. 54:1-15.

Rodrigo MA, Rojo C, Segura M, Alonso-Guillén JL, Martín M,
Vera P, 2015. The role of charophytes in a Mediterranean pond created for restoration purposes. Aquat. Bot. 120:101-111.

Rossi L, Costantini ML, Carlino P, di Lascio A, Rossi D, 2010. Autochthonous and allochthonous plant contributions to coastal benthic detritus deposits: a dual-stable isotope study in a volcanic lake. Aquat. Sci. 72:227-236.

Sebastián-González E, Navarro J, Sánchez-Zapata JA, Botella F, Delgado A, 2012. Water quality and avian inputs as sources of isotopic variability in aquatic macrophytes and macroinvertebrates. J. Limnol. 71:191-199.

Sierzen ME, Peterson GS, Trebitz AS, Brazner JC, West CW, 2006. Hydrology and nutrient effects on food-web structure in ten Lake Superior coastal wetlands. Wetlands 26:951-964.

Syväranta J, Hämäläinen H, Jones RI, 2006. Within-lake variability in carbon and nitrogen stable isotope signatures. Freshwater Biol. 51:1090-1102.

Thornton SF, Mcmanus J, 1994. Application of organic-carbon and nitrogen stable-isotope and $\mathrm{C} / \mathrm{N}$ ratios as source indicators of organic-matter provenance in estuarine systems - evidence from the Tay estuary, Scotland. Estuar. Coast. Shelf Sci. 38:219-233.

Vander Zanden MJ, Rasmussen JB, 2001. Variation in $\delta^{15} \mathrm{~N}$ and $\delta^{13} \mathrm{C}$ trophic fractionation: Implications for aquatic food web studies. Limnol. Oceanogr. 46:2061-2066.

Vermeer CP, Escher M, Portielje R, De Kle M, 2003. Nitrogen uptake and translocation by Chara. Aquat. Bot. 76:245-258.

Wang J, Zamar R, Marazzi A, Yohai V, Salibian-Barrera M, Maronna R, Zivot E, Rocke D, Martin D, Maechler M, Konis K, 2010. Robust: Insightful Robust Library. R package version 0.3-11.

Wetzel RG, Brammer ES, Lindstrom K, Forsberg C, 1985. Photosynthesis of submersed macrophytes in acidified lakes. II. Carbon limitation and utilization of benthic $\mathrm{CO}_{2}$ sources. Aquat. Bot. 22:107-120. 